\title{
ZIELEŃ WODNA I TERENÓW ZALEWOWYCH W PARKU WODNYM W POZNANIU
}

\author{
WATER GREENERY AND FLOODPLAINS IN THE WATER PARK IN POZNAŃ
}

\author{
Pawe€ Piotr SzumigaŁa, Piotr Urbański, MiŁosz Walerzak, Karolina SzumigaŁa \\ K. Szumigała, studentka Wydziału Architektury Politechniki Poznańskiej, ul. Nieszawska 13, 61-021 Poznań, \\ Poland, e-mail: karolina.szumigala@wp.pl \\ P.P. Szumigała, Katedra Terenów Zieleni i Architektury Krajobrazu, Uniwersytet Przyrodniczy w Poznaniu, \\ ul. Dąbrowskiego 159, 60-594 Poznań, Poland, e-mail: pawel.szumigala@up.poznań.pl \\ P. Urbański, Katedra Terenów Zieleni i Architektury Krajobrazu, Uniwersytet Przyrodniczy w Poznaniu, \\ ul. Dąbrowskiego 159, 60-594 Poznań, Poland, e-mail: piotr.urbanski@up.poznan.pl
}

M. Walerzak, Katedra Terenów Zieleni i Architektury Krajobrazu, Uniwersytet Przyrodniczy w Poznaniu, ul. Dąbrowskiego 159, 60-594 Poznań, Poland, e-mail: milosz.walerzak@up.poznań.pl

(Received: September 28, 2018. Accepted: October 21, 2018)

\begin{abstract}
AвSTRACT. The article presents the issues related to the use of greenery in the desing of public spaces on the example of the development project of the Water Park in Poznań. Composition, natural and environmental issues concerning a selected part of the park, i.e. the zone of leading greenery in the vicinity of the water pond, were discussed. The presented implementation arguments are the basis for recreating in this part of the park as a landscape with natural values of city space.
\end{abstract}

KeY WORDs: greenery, land development, Water Park, Poznań

\section{WSTĘP}

Projektowany park Wodny w Poznaniu powstanie w zakolu rzeki Warty, położonym na południe od ujęcia wody na Dębinie (ryc. 1).

Teren od strony zachodniej, północnej i południowej przylega do zakola Warty, a od strony wschodniej sąsiaduje $z$ terenami mieszkaniowymi obrębu Starołęka Wielka i Marlewo w dzielnicy Nowe Miasto. Obszar parku to $\mathrm{w}$ przeważającej części tereny zalewowe rzeki Warty. Przeważają tu łąki podmokłe oraz na skraju południowym i wzdłuż brzegu Warty pasma zadrzewień i pojedyncze grupy drzew towarzyszące zabudowie mieszkaniowej przy ul. Starołęckiej. Hipsometria terenu sprzyja zalewom i powstawaniu zastoisk wody oraz obszarów bagiennych, dlatego jego użyteczność w aspekcie inwestycyjnym jest mała.

Ryc. 1. Lokalizacja parku Wodnego w Poznaniu Źródło: opracowanie K. Szumigała.

Fig. 1. Location of the Water Park in Poznań Source: study of K. Szumigała.

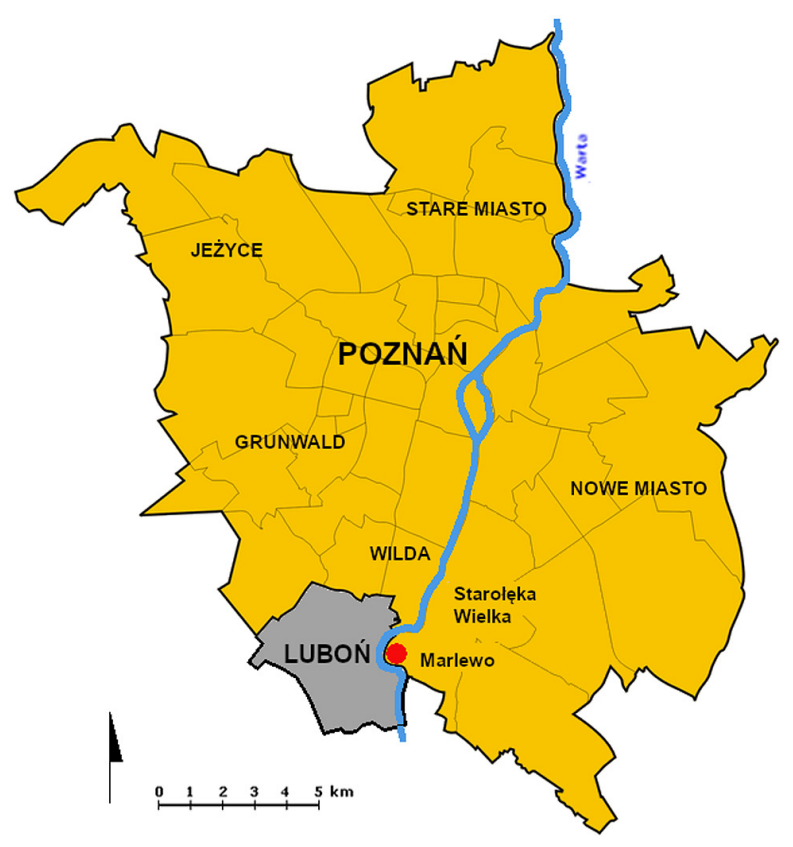


Obszar ten ma jednak znaczny potencjał biologiczny i dobre walory środowiskowe dla rozwoju fauny i flory terenów wodnych i podmokłych. Istotnym walorem przestrzenno-krajobrazowym jest także dobra ekspozycja widokowa $z$ drugiego brzegu rzeki Warty, od strony miasta Luboń, graniczącego z projektowanym parkiem Wodnym. Właśnie na obszarze Lubonia, w rejonie byłych zakładów ziemniaczanych, które są obecnie atrakcyjnym terenem inwestycyjnym, będzie mogła powstać promenada spacerowa na wysokim lewym brzegu Warty, z którego rozpościera się widok na zakole rzeki i tereny parku Wodnego. Koncepcję zagospodarowania parku Wodnego i lewego brzegu Warty przedstawiono na rycinie 2 .

Projektowanie na terenach zalewowych wiąże się $z$ koniecznością uwzględnienia wielu wymagań, głównie środowiskowych oraz planistycznych ${ }^{1}$. Istotny w tym wypadku był również aspekt użytkowy. W projekcie wzięto pod uwagę zapotrzebowanie społeczne na tereny wypoczynku i rekreacji o szczególnych funkcjach środowiskowych. Projektanci planu zagospodarowania parku spełnili powyższe warunki dzięki podzieleniu przestrzeni parku na kilka stref o odmiennym charakterze. Największą strefą pod względem powierzchni jest zbiornik wodny $z$ okalającym go obszarem nasadzeń ozdobnych. Od strony północnej, wschodniej i południowej park posiada otulinę - obszar będący buforem przestrzenno-krajobrazowym, który oddziela teren parku od zabudowy mieszkaniowej przy ul. Starołęckiej. W części południowej parku wydzielono parking wraz $z$ dojazdem. Istotnym elementem zagospodarowania obszaru parku było odtworzenie przestrzeni o walorach zbliżonych do krajobrazu naturalnego, występującego na terenach podmokłych $z$ dużym udziałem wód powierzchniowych. Cechą charakterystyczną tego krajobrazu jest zieleń terenów podmokłych, bagiennych i zalewowych oraz zieleń wodna. W projekcie zagospodarowania parku zaplanowano zatem zbiornik wodny wraz z wyspami, które tworzą system połączeń wodnych o charakterze zbliżonym do siedlisk naturalnych. Głównym elementem kompozycji jest duży zbiornik wodny - staw, obsadzony pasmami roślinności charakterystycznej dla strefy brzegowej zbiorników wodnych, z licznymi enklawami roślinności wkomponowanej $\mathrm{w}$ system wysepek i połączeń wodnych pomiędzy nimi. Pasma roślin ozdobnych i kwitnących mają kształt owalu obiegającego staw, natomiast enklawy zieleni rozmieszczone na wyspach i w sąsiedztwie zbiornika mają formę nieregularnych plam. W zbiorniku wodnym zaplanowano nasadzenia kwitnącymi roślinami wodnymi. Funkcję użytkową będzie spełniało przejście spacerowe, umożliwiające podziwianie walorów krajobrazowych,

1 Miejscowy plan zagospodarowania przestrzennego dla obszaru „Rejon Marlewa - Zakole Warty” w Poznaniu uchwała nr LXXX/1204/V/2010 Rady Miasta Poznania $\mathrm{z}$ dnia 9 listopada 2010. zlokalizowane na terenie parku Wodnego. W tym celu przewidziano i zaprojektowano ścieżkę pieszą o swobodnym, zbliżonym do naturalnego przebiegu $\mathrm{w}$ postaci drewnianej kładki zawieszonej nad wodą. Kładka ma początek na prawym brzegu Warty, w południowym skraju parku, prowadzi kolejno przez wszystkie wysepki i obiega dookoła główny zbiornik (ryc. 3). Dobór gatunków i zaproponowana kompozycja nasadzeń umożliwia uzyskanie fragmentu przestrzeni o charakterze naturalnym, spełniającym także funkcję ozdobną i wypoczynkową. Istotnym aspektem planu zagospodarowania tego obszaru było nawiązanie do cech przestrzeni naturalnej terenów podmokłych we współczesnej formie.

Celem prezentowanej koncepcji zagospodarowania terenu jest zachowanie walorów krajobrazowych

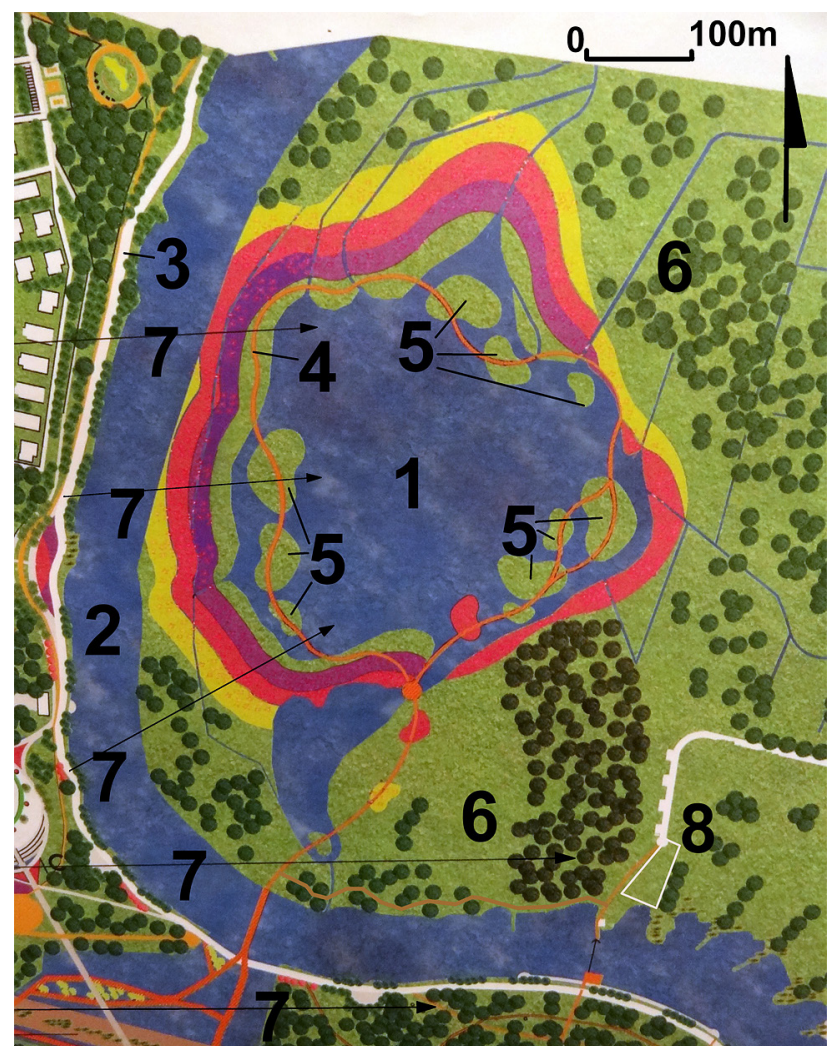

Ryc. 2. Schemat zagospodarowania parku Wodnego w Poznaniu: 1 - „staw” - zbiornik wodny z wyspami, - strefa rekreacji czynnej, 2 - rzeka Warta, 3 - promenada w Luboniu na lewym brzegu Warty, 4 - ścieżka spacerowa - pomost, 5 - wyspy, 6 - otulina parku z nowymi zadrzewieniami, 7 - kierunki widokowe z promenady w Luboniu, 8 - parking leśny i droga dojazdowa

Źródło: opracowanie. K. Szumigała na podstawie: JARos i in. (2014), Projekt zagospodarowania fragmentu Lubonia, KTZiAK UP Poznań.

Fig. 2. Scheme of development of Water Park in Poznań: 1 - "pond" - water reservoir with islands, - active recreation zone, 2 - Warta river, 3 - promenade in Luboń on the left bank of the Warta river, 4 - walking path pier, 5 - islands, 6 - park buffer zone with new trees, 7 - viewing directions from the promenade in Lubon, 8 - forest parking and access road

Source: study of K. Szumigała on the basis of: JAROs et al. (2014), Project of development of a fragment of Luboń, KTZiAK UP Poznań. 


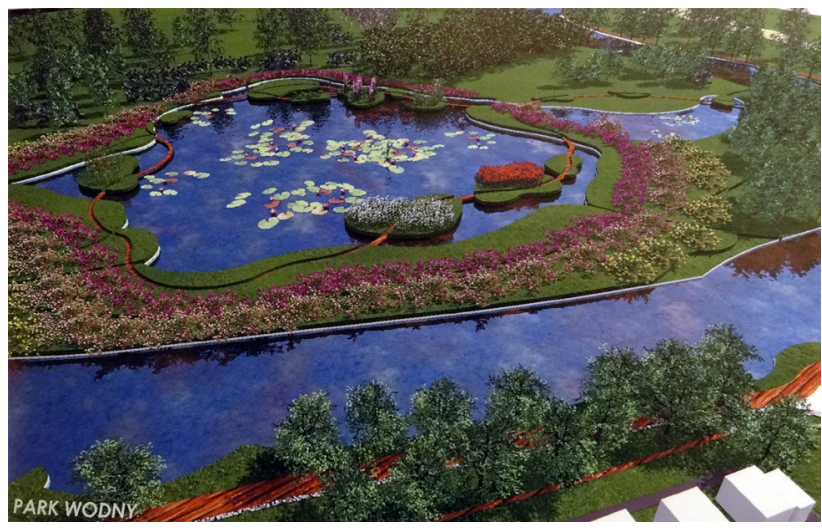

Ryc. 3. Wizualizacja parku Wodnego w Poznaniu - widok na park $z$ promenady $w$ Luboniu

Źródło: opracowanie P.P. Szumigała, K. Szumigała na podstawie: JAROS i in. (2014), Projekt zagospodarowania fragmentu Lubonia, KTZiAK UP Poznań.

Fig. 3. Visualization of the Water Park in Poznan - view of the park from promenade in Luboń

Source: study of P.P. Szumigała, K. Szumigała on the basis of: JAros et al. (2014), Project of development of a fragment of Lubon, KTZiAK UP Poznań

i środowiskowych tego fragmentu miasta Poznania oraz zaspokojenie potrzeb jego mieszkańców na aktywny i bierny wypoczynek w miejscu o dużych walorach estetycznych. Eksploatacja turystyczna i wypoczynkowa projektowanego obszaru została zaplanowana jako ekstensywna, bezpośrednia i okresowa penetracja tego miejsca w małych grupach, w celu zachowania równowagi klimatu akustycznego i ochrony w okresach lęgowych występujących na tym obszarze miejsc gniazdowania ptaków ${ }^{2}$. Park Wodny zaplanowano jako barwny fragment krajobrazu miasta mający służyć wielopokoleniowemu odbiorcy (dzieciom, młodzieży i dorosłym), przewidziany zarówno do obserwacji z lewego brzegu Warty, jak i do odbioru bezpośredniego podczas zwiedzania parku. Proponowana wielopokoleniowość potencjalnych użytkowników parku ma aspekt społeczny i dydaktyczny. Wspólny wypoczynek i czas spędzony na łonie natury sprzyja bowiem integracji na poziomie rodziny, wspomaga procesy poznawania otaczającego nas środowiska oraz uczy młode pokolenia poszanowania dla przyrody.

\section{MATERIAŁ I METODY}

\section{ZAŁOŻENIA KOMPOZYCYJNE PARKU WODNEGO}

Obszar parku Wodnego wraz z otuliną wynosi 43,3 ha i obejmuje teren ograniczony od stron: poludniowej, zachodniej i północnej zakolem Warty, a od strony wschodniej ulicą Starołęcką. Najcenniejszymi elementami parku są zastoiska wody oraz mniejsze

2 Prognoza oddziaływania na środowisko na potrzeby miejscowego planu zagospodarowania przestrzennego dla obszaru „Rejon Marlewa - Zakole Warty” w Poznaniu. zbiorniki wodne powstałe po zalewach rzeki, łąki i gleby nawodnione - $\left(\mathrm{Gw}^{3}\right)$ terenów podmokłych oraz roślinność wodna i łąkowa charakterystyczna dla obszarów podmokłych. Obecnie na tym terenie występują powszechnie zbiorowiska: olszy czarnej (Alnus glutinosa 'Aurea'), wiązówki błotnej (Filipendula ulmaria) i traw. Koncepcja zagospodarowania przestrzennego parku Wodnego przewiduje budowę zbiornika wodnego o powierzchni ok. 13,6 ha i pojemności ok. 153 tys. $\mathrm{m}^{3}$. Zbiornik będzie zasilany wodami istniejącego cieku wraz z małym stawem po jego stronie południowej. Nadmiar wód po zalewach rzeki Warty oraz wód opadowych odprowadzają małe cieki wodne znajdujące się po stronie północnej. Przepływ wody w planowanym zbiorniku będzie się odbywał w tym samym kierunku, w którym płyną wody Warty, tj. $z$ południa na północ.

W strefie brzegowej zbiornika zaplanowano 11 wysp: pięć większych o powierzchni ok. 1100-1300 $\mathrm{m}^{2}$ i sześć mniejszych o powierzchni $300-400 \mathrm{~m}^{2}$. Wyspy rozmieszczono $\mathrm{w}$ trzech grupach $\mathrm{w}$ zakolach brzegu zbiornika. Ustalono podobne odległości pomiędzy wyspami w danej grupie. Linie brzegowa zbiornika i wysp mają nieregularne kształty, nawiązujące do układów naturalnych. W projekcie przewidziano połączenie wszystkich wysp ze sobą i z brzegiem zbiornika planowaną ścieżką spacerową w formie kładki - długiego pomostu zawieszonego nad taflą wody i nad powierzchniami wysp. Długość planowanej ścieżki wynosi $1600 \mathrm{~m}$, a szerokość $4 \mathrm{~m}$. Konstrukcję podpierającą ścieżki stanowią betonowe słupki zakotwione $\mathrm{w}$ gruncie i $\mathrm{w}$ dnie zbiornika. Płaszczyzna ruchu (nawierzchnia pomostu) będzie wykonana $z$ ryflowanego drewna. Przebieg ścieżki zaplanowano tak, aby jej użytkownik miał możliwość oglądania roślinności występującej w różnych strefach zbiornika, wysp i terenu przyległego do zbiornika. Ścieżka zaczyna się w południowej strefie parku, przy brzegu rzeki Warty, gdzie zaplanowano dojazd i parking leśny dla odwiedzających park oraz kładkę (most) przez Wartę, łączącą promenadę w Luboniu z parkiem Wodnym. Miejsca postojowe zostały utwardzone za pomocą ekokrat trawnikowo-parkingowych. Dojazd do parkingu przewidziano od strony ulicy Starołęckiej.

Według mapy sozologicznej południowego Poznania 1:50 000. Materiały zebrał i opracował zespół naukowy, którego głównym konsultantem był prof. dr hab. Stefan Żynda (UAM Poznań). Mapę przygotowano do druku w Wielkopolskim Przedsiębiorstwie Geodezyjno-Kartograficznym GEOMAT Sp. z o.o. w Poznaniu i zamieszczono zgodnie z zezwoleniem Marszałka Województwa Wielkopolskiego nr 5/2005 z dnia 23 listopada 2005 r. Źródło: https://www.google.pl/search?q=mapa+sozologiczna+po\%C5\%82udniowego + Poznania\&o$\mathrm{q}=$ mapa +sozologiczna+po\%C5\%82udniowego + Poznania\&aqs = chrome..69i57.21727j1j7\&sourceid $=$ chrome\&ie $=$ UTF-8 (dostęp: 27.11.2018). 
Istotnym elementem zagospodarowania terenów przyległych do parku jest propozycja budowy promenady wzdłuż zachodniego brzegu zakola Warty, w rejonie byłych zakładów ziemniaczanych w Luboniu. Na tym zachodnim odcinku rzeka ma wysoki brzeg, umożliwiający rozległy widok na koryto Warty i tereny po drugiej stronie rzeki. Planowana promenada w Luboniu to ciąg spacerowo-widokowy, z którego rozpościera się panorama na obszary zalewowe Starołęki, Marlewa i planowanego parku Wodnego. Jest to bardzo istotny aspekt prezentacji i ekspozycji walorów estetycznych parku Wodnego, gdyż jest on wówczas widoczny z góry. Taka ekspozycja walorów parku umożliwia doznania estetyczne odmienne od odczuwanych podczas jego bezpośredniej penetracji i poznawania z poziomu ścieżki - pomostu spacerowego. Stanowi to dodatkowy i atrakcyjny aspekt turystyczny oraz dydaktyczny, wpływający na kształtowanie proekologicznych i proestetycznych postaw społeczeństwa, szczególnie młodego pokolenia. W dobie wszechobecnych technologii cyfrowych ten element kształtowania postaw i zainteresowań ludzi oraz sposobów spędzania przez nich wolnego czasu nabiera szczególnego społecznego znaczenia.

W kompozycji parku i w panoramie na miasto zastosowano metodę rekompozycji widoku przez uzupełnienie i dopełnienie panoramy o elementy pierwszego planu (podstawy panoramy) w postaci stawu i strefy nasadzeń zielenią wodną, przywodną, terenów podmokłych - zalewowych, łąkową oraz nowym drzewostanem. Elementy te decydują w głównej mierze o wytworzeniu przestrzeni o charakterze zbliżonym do krajobrazu otwartego terenów zalewowych. W planie zagospodarowania parku wydzielono część nawiązującą do naturalnego środowiska wraz ze ścieżką spacerową. Strefy i enklawy zieleni wodnej i przywodnej to zasadniczy element części rekreacyjno-dydaktycznej parku. Jest ona uzupełnieniem pierwszego planu - podstawy panoramy widoku z lewego brzegu rzeki Warty na Starołękę i Marlewo, pełni również funkcję strefy ozdobnej.

Przedmiotem badań niniejszej rozprawy są enklawy zieleni przywodnej, które $\mathrm{w}$ projekcie parku określono mianem: „owal”, „plamy”, „staw” i otulina parku. W badaniach zastosowano metodę analizy kompozycyjnej ekspozycji widoku krajobrazowego przez rekompozycję krajobrazu i renaturyzację środowiska oraz analizę struktur zieleni i zasadę doboru gatunkowego do warunków siedliskowych.

\section{WYNIKI I DYSKUSJA}

\section{ELEMENTY ZAGOSPODAROWANIA STREFY ZIELENI WODNEJ I TERENÓW ZALEWOWYCH}

Zieleń parku składa się z roślinności istniejących łąk oraz zieleni projektowanej, którą przewidziano w postaci „ozdobnych owali”, enklaw, stawu i otuliny par$\mathrm{ku}$. W skład zieleni projektowanej zaliczono rodzime gatunki zieleni wodnej, przywodnej i terenów podmokłych oraz roślin o interesujących walorach estetycznych, występujących na innych szerokościach geograficznych, aplikowanych do krajowych warunków siedliskowych. O wykorzystaniu w tej kompozycji również gatunków obcych zadecydowały przede wszystkim ich pokrój i barwa, które nawiązują do form roślin rodzimych. Zastosowano 27 gatunków roślin: 4 gatunki drzew, 9 gatunków krzewów, 10 gatunków bylin, w tym 5 gatunków roślin wodnych oraz 4 gatunki traw w miejscach podlegających przebudowie. Projektowane nasadzenia przewidziano $\mathrm{w}$ formie "owalu" i zlokalizowano w pasie brzegowym stawu zbiornika wodnego. Drugą grupą nowych nasadzeń będą enklawy zieleni - „plamy swobodnie rozrzucone" po terenie i wyspach. Trzecią grupą będzie zieleń wodna w planowanym zbiorniku - „stawie” Struktura, rozkład i formy nowych nasadzeń zostały zaplanowane tak, aby podkreślały naturalny charakter miejsca i nawiązywały do krajobrazu nadwarciańskich terenów zalewowych w południowej części Poznania. Projektowane owale roślinne, uformowane $\mathrm{w}$ postaci współśrodkowych pasów nasadzeń dokoła stawu, podkreślą naturalny, „swobodny” układ przestrzenny oraz linię brzegową. Utworzą jednocześnie kompozycję roślin drugiego piętra, pomiędzy najniżej usytuowaną powierzchnią łąk a najwyższym piętrem

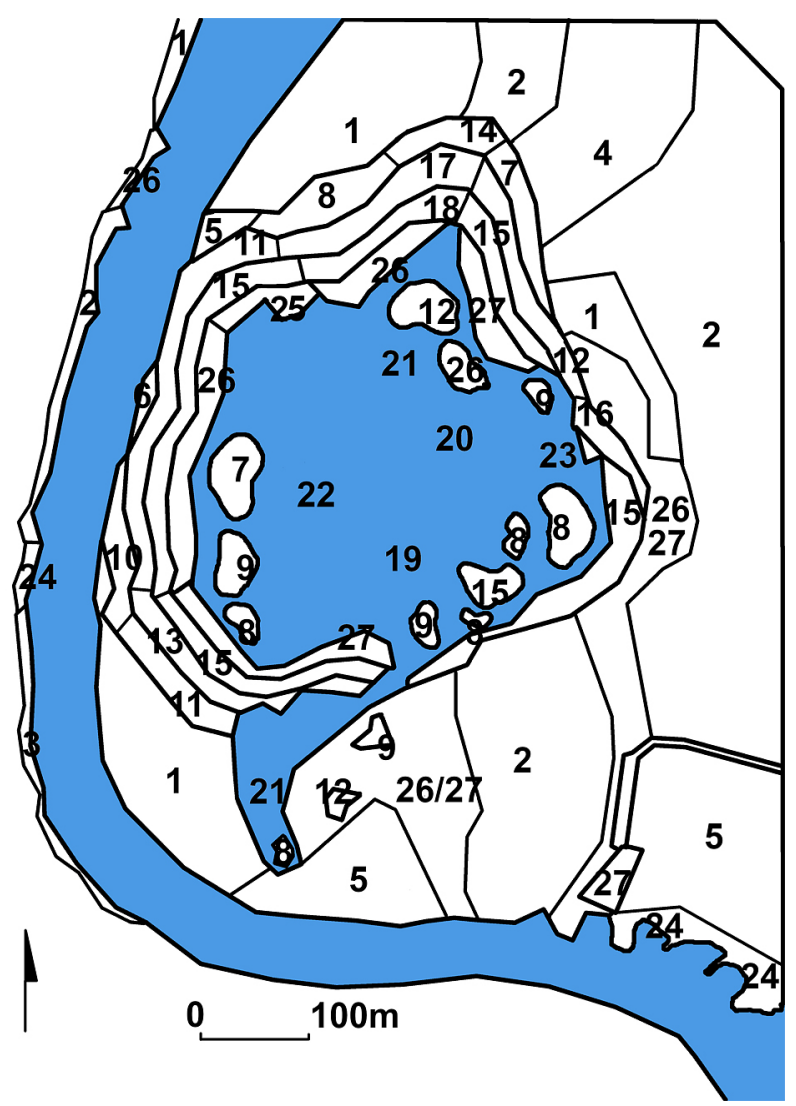

Ryc. 4. Struktura nasadzeń parku Wodnego w Poznaniu Źródło: opracowanie K. Szumigała.

Fig. 4. Structure of planting of the Water Park in Poznań Source: study of K. Szumigała. 
Tabela 1. Proponowane gatunki drzew, krzewów, bylin i roślin wodnych w parku Wodnym Table 1. Proposed species of trees,shrubs, perennials and aquatic plants in the Water Park

\begin{tabular}{|c|c|c|c|c|c|}
\hline \multicolumn{6}{|c|}{$\begin{array}{l}\text { Wykaz roślin } \\
\text { List of plants }\end{array}$} \\
\hline $\mathrm{Nr}$ & Nazwa łacińska & Nazwa polska & Liczba & Więźba & Powierzchnia $\left(\mathrm{m}^{2}\right)$ \\
\hline No & Latin name & Polish name & Number & Lift & Area $\left(m^{2}\right)$ \\
\hline \multicolumn{6}{|c|}{$\begin{array}{c}\text { Drzewa } \\
\text { Trees }\end{array}$} \\
\hline $1^{*}$ & Salix purpurea 'Nana' L. & wierzba purpurowa & 5180 & $10 \mathrm{~m} \times 10 \mathrm{~m}$ & 51800 \\
\hline $2^{*}$ & Alnus glutinosa 'Aurea' & olsza czarna & 13278 & $10 \mathrm{~m} \times 10 \mathrm{~m}$ & 132780 \\
\hline $3^{*}$ & Alnus incana 'Laciniata' & olsza szara & 325 & $10 \mathrm{~m} \times 10 \mathrm{~m}$ & 3250 \\
\hline $4^{*}$ & Alnus incana 'Pendula' & olsza szara & 2113 & $10 \mathrm{~m} \times 10 \mathrm{~m}$ & 21130 \\
\hline \multicolumn{6}{|c|}{$\begin{array}{l}\text { Krzewy } \\
\text { Bushes }\end{array}$} \\
\hline $5^{*}$ & Pterocaya fraxinifolia & skrzydłorzech kaukaski & 3265 & $10 \mathrm{~m} \times 10 \mathrm{~m}$ & 32650 \\
\hline $6^{*}$ & Cornus alba & dereń biały & 500 & $1 \mathrm{~m} \times 1 \mathrm{~m}$ & 500 \\
\hline $7^{*}$ & Cornus stolonifera & dereń rozłogowy & 5800 & $1 \mathrm{~m} \times 1 \mathrm{~m}$ & 5800 \\
\hline $8^{*}$ & Cornus alba 'Aurea' & dereń biały & 9180 & $1 \mathrm{~m} \times 1 \mathrm{~m}$ & 9180 \\
\hline $9^{*}$ & Cornus alba 'Sibirica' & dereń biały & 3650 & $1 \mathrm{~m} \times 1 \mathrm{~m}$ & 3650 \\
\hline $10^{*}$ & Cornus alba 'Sibirica variegata' & dereń biały & 3000 & $1 \mathrm{~m} \times 1 \mathrm{~m}$ & 3000 \\
\hline $11^{*}$ & Cornus alba 'Spaethii' & dereń biały & 11300 & $1 \mathrm{~m} \times 1 \mathrm{~m}$ & 11300 \\
\hline $12^{*}$ & Viburnum opulus & kalina koralowa & 7000 & $1 \mathrm{~m} \times 1 \mathrm{~m}$ & 7000 \\
\hline $13^{*}$ & Spiraea japonica 'Nana' & tawuła japońska & 3400 & $1 \mathrm{~m} \times 1 \mathrm{~m}$ & 3400 \\
\hline \multicolumn{6}{|c|}{$\begin{array}{l}\text { Byliny i rośliny wodne } \\
\text { Perennials and aquatic plants }\end{array}$} \\
\hline $14^{*}$ & Filipendula ulmaria & wiązówka błotna & 25650 & $5 \mathrm{szt} . / \mathrm{m}^{2}$ & 5130 \\
\hline & Lythrum salicaria & krwawnica pospolita & 107500 & $5 \mathrm{szt} . / \mathrm{m}^{2}$ & 21500 \\
\hline $16^{*}$ & Polemonium caeruleum 'Album' & wielosił błękitny (biało kwitnący) & 1400 & $7 \mathrm{szt} . / \mathrm{m}^{2}$ & 200 \\
\hline $17^{*}$ & Lysimachia punctata & tojeść kropkowana & 50000 & $10 \mathrm{szt} . / \mathrm{m}^{2}$ & 5000 \\
\hline $18^{*}$ & Astible $\times$ arenci 'Fanal' & tawułka Arendsa różowo-czerwona & 17000 & $5 \mathrm{szt} . / \mathrm{m}^{2}$ & 3400 \\
\hline $19 *$ & Nuphar lutea & grążel żółty & 1000 & $1 \mathrm{szt} . / 10 \mathrm{~m}^{2}$ & 10000 \\
\hline $20^{*}$ & Nymphaea alba & grzybień & 1000 & $1 \mathrm{szt} . / 10 \mathrm{~m}^{2}$ & 10000 \\
\hline $21^{*}$ & Nymphaea 'Andreana' & grzybień & 1300 & $1 \mathrm{szt} . / 10 \mathrm{~m}^{2}$ & 13000 \\
\hline $22^{*}$ & Nymphaea 'Gonnere' & grzybień & 1000 & $1 \mathrm{szt} . / 10 \mathrm{~m}^{2}$ & 10000 \\
\hline $23^{*}$ & Nymphaea 'Marliacea Albida' & grzybień & 1000 & $1 \mathrm{szt} . / 10 \mathrm{~m}^{2}$ & 10000 \\
\hline \multicolumn{6}{|c|}{$\begin{array}{l}\text { Trawy } \\
\text { Grass }\end{array}$} \\
\hline $24^{*}$ & Miscanthus sacchariflorus & miskant cukrowy & 11550 & $3 \mathrm{szt} . / \mathrm{m}^{2}$ & 3850 \\
\hline $25^{*}$ & Spatina pectinata 'Aureomarginata' & spartyna grzebieniasta & 8400 & $3 \mathrm{szt} . / \mathrm{m}^{2}$ & 2800 \\
\hline $26^{*}$ & Lolium perenne $\mathrm{L}$. & życica trwała & $3310 \mathrm{~kg}$ & $1 \mathrm{~kg} / 5 \mathrm{~m}^{2}$ & 16550 \\
\hline \multirow{2}{*}{\multicolumn{2}{|c|}{ 27* Festuca pratensis Huds. }} & kostrzewa łąkowa & $6800 \mathrm{~kg}$ & $1 \mathrm{~kg} / 5 \mathrm{~m}^{2}$ & 34000 \\
\hline & & & $\begin{array}{l}294791 \mathrm{roślin} / \text { plants } \\
10110 \mathrm{~kg} \text { traw/grasses }\end{array}$ & & 432850 \\
\hline
\end{tabular}

Źródło: opracowali P.P. Szumigała, K. Szumigała.

Source: study of P. P. Szumigała, K. Szumigała.

widocznym w sąsiedztwie - drzewostanem porastającym wschodnią i południową strefę terenów zalewowych zakola Warty. Rośliny zastosowane w kompozycji „owali i plam” są zróżnicowane pod względem wysokości, formy, pokroju oraz barwy i nawiązują do naturalnych układów roślinności przywodnej i terenów podmokłych bagiennych oraz roślinności wodnej i łąkowej występującej w środowisku naturalnym na terenach zalewowych. Projektowane „owale” składają się z pełnych zamkniętych dwóch pasów zlokalizowanych dokoła zbiornika oraz fragmentów - odcinków zlokalizowanych $\mathrm{w}$ trzecim zewnętrznym pasie na skraju północnym i zachodnim. Projektowane „plamy zieleni" usytuowano na wyspach oraz w różnych swobodnych układach i strukturach na terenie sąsiadującym ze zbiornikiem i Wartą. Strukturę nasadzeń przedstawiano na rycinie 4 .

W kompozycji nasadzeń zastosowano rośliny, które zestawiono w tabeli 1 i opisano poniżej (wybrane gatunki).

\section{WIERZBA PURPUROWA 'NANA' (SALIX PURPUREA 'NANA')}

Kulisty, gęsty krzew z licznymi, delikatnymi pędami o brązowoczerwonej barwie. Dorasta do $2 \mathrm{~m}$. Liście lancetowate, srebrzystoszare. Niewymagający, dobrze rosnący na glebach umiarkowanie suchych 


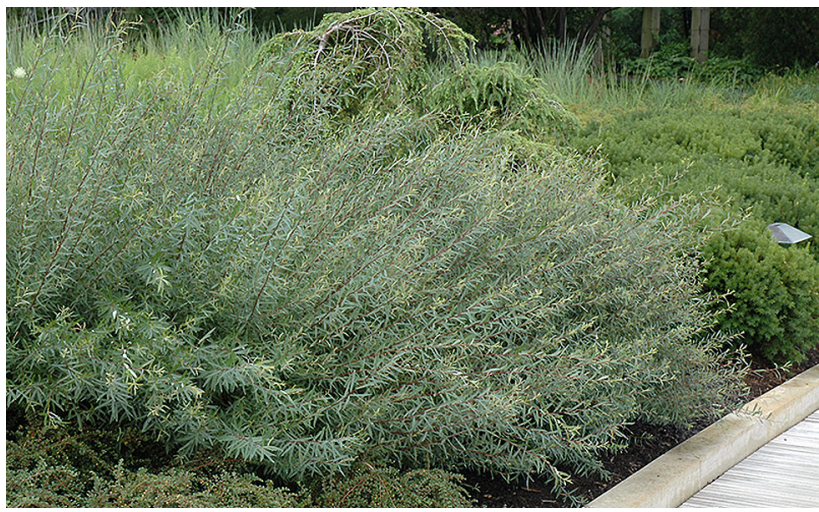

Fot. 1. Salix purpurea 'Nana' Źródło: [1].

Phot. 1. Salix purpurea 'Nana' Source: [1].

i całkowicie mokrych, od średnio kwaśnych do całkiem alkalicznych. Toleruje mrozy i upały. Stanowisko słoneczne do lekko cienistego. Wymaga cięcia.

Do nasadzeń przewidziano rośliny dostosowane do istniejących warunków klimatyczno-glebowych, o szczególnych walorach dekoracyjnych, zróżnicowane pod względem pokroju i barw, zarówno liściaste, jak i iglaste - zimozielone oraz zrzucające liście na zimę (fot. 1).

\section{DEREN BIAŁY (CORNUS ALBA 'SIBIRICA')}

Krzew liściasty o pokroju wyniosłej wiechy, dorasta do $3 \mathrm{~m}$. Liście tej odmiany są żywozielone, na jesieni przebarwiają się na kolor jaskrawoczerwony. Po

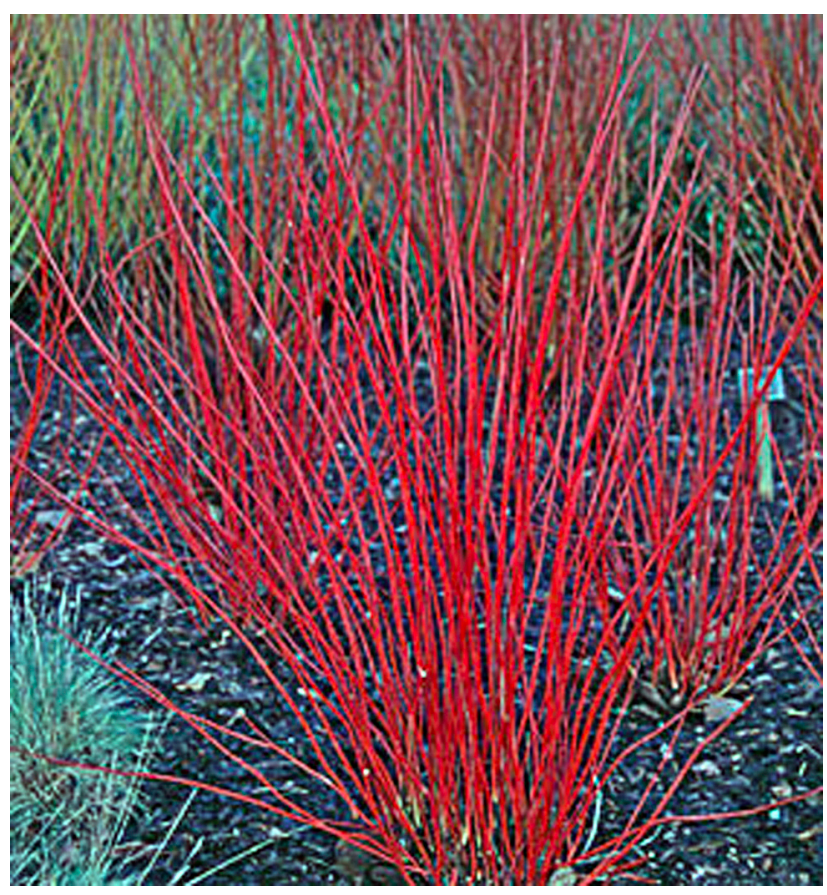

Fot. 2. Krzew Cornus alba 'Sibirica' w stanie bezlistnym Źródło: [2].

Phot. 2. Leafless bush Cornus alba 'Sibirica' Source: [2]. utracie liści widoczne są wyprostowane czerwone pędy, które najkorzystniej prezentują się na tle białego śniegu i wczesną wiosną. Kwitnie w lipcu i sierpniu. Kwiaty drobne, kremowe, baldachowate na końcach pędów. Owocuje dwa miesiące później, wówczas białe owoce bardzo ładnie kontrastują z przebarwiającymi się już liśćmi. Ma małe wymagania glebowe, jednak najlepiej rośnie w glebie żyznej i lekko wilgotnej. Stanowiska słoneczne i w półcieniu. Krzew sadzony w grupach i pojedynczo. Ma szczególne walory dekoracyjne, zarówno w postaci formowanej, jak i naturalnej (fot. 2).

\section{KALINA KORALOWA (VIBURNUM OPULUS)}

Okazały krzew o głęboko powcinanych klapowanych liściach, rośnie do $4 \mathrm{~m}$ wysokości i rozrasta się szeroko za pomocą odrostów korzeniowych. Liście zielone, zielonożółte lub żółte. Kwitnie latem - duże białe kuliste kwiatostany o średnicy ok. $10 \mathrm{~cm}$. Owocuje w sierpniu w postaci przeźroczystych krwistoczerwonych kulek uformowanych w zwisające kiście. Jesienią liście przebarwiają się na czerwono i opadają. Ma małe wymagania: gleba - odczyn obojętny, umiarkowanie wilgotna, stonowisko - słoneczne lub półcień (fot. 3).

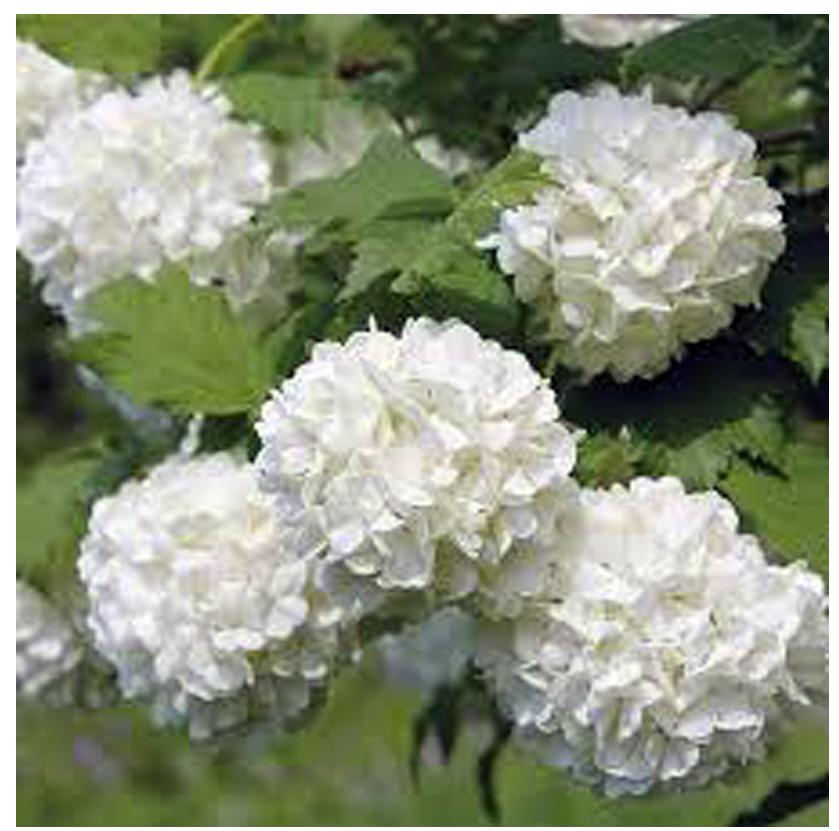

Fot. 3. Viburnum opulus

Źródło: [3].

Phot. 3. Viburnum opulus

Source: [3].

\section{KRWAWNICA POSPOLITA (LYTHRUM SALICARIA)}

Należy do rodziny Lythraceae - krwawnicowate. Występuje na całej półkuli północnej i w Australii, pospolita także na terenie Polski. Łodygi rośliny są pojedyncze lub z nielicznymi, krótkimi odgałęzieniami, 


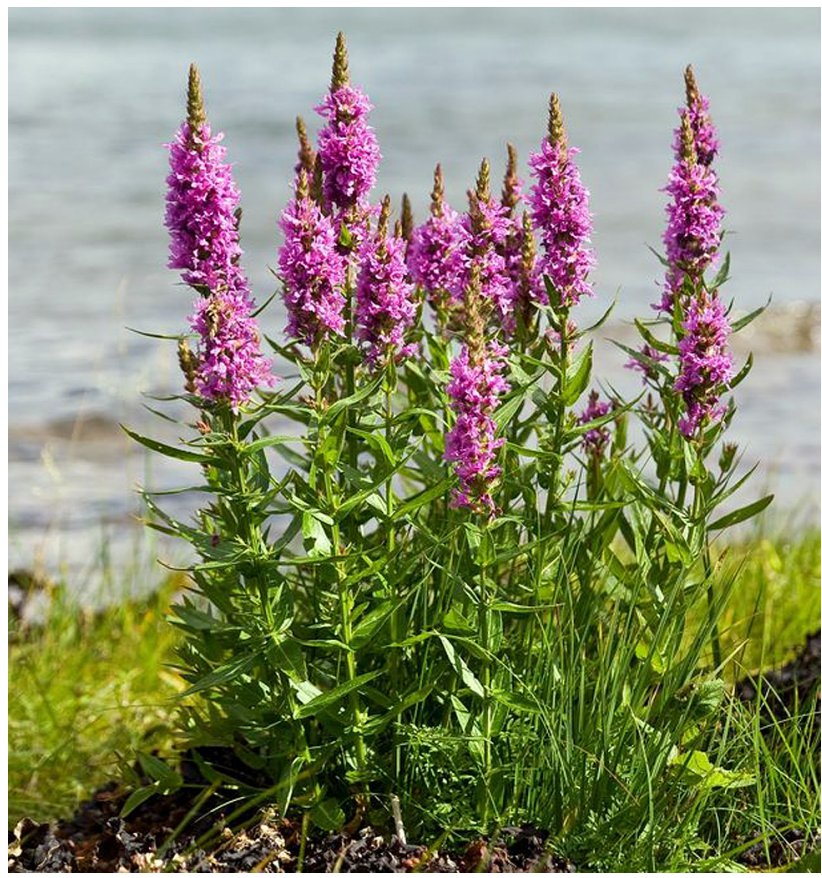

Fot. 4. Lythrum salicaria

Źródło: [4].

Phot. 4. Lythrum salicaria

Source: [4].

wyprostowane, owłosione, osiągają około $100 \mathrm{~cm}$ wysokości. W sprzyjających warunkach mogą uzyskać wysokość $150 \mathrm{~cm}$. Dolne liście są sercowate, górne łodygowe mają kształt wąskolancetowaty i są ułożone naprzeciwlegle po 2 lub 3 w okółkach. Karminoworóżowe kwiaty są zebrane $\mathrm{w}$ długie $($ do $30 \mathrm{~cm}$ ) kłosowate kwiatostany, bardzo chętnie odwiedzane przez motyle i pszczoły. Kwitnienie przypada na okres lipca i sierpnia. Lythrum salicaria jest sadzona na stanowiskach słonecznych, nadwodnych lub na wilgotnych, próchnicznych rabatach, ponieważ $\mathrm{w}$ takich warunkach czuje się najlepiej. Na glebach suchych nie wyrasta do typowej wysokości (fot. 4).

\section{TOJEŚĆ KROPKOWANA (LYSIMACHIA PUNCTATA)}

Należy do rodziny Primulaceae - pierwiosnkowate. Gatunek występuje w południowo-wschodniej części kraju, w miejscach raczej wilgotnych. Ma krótkie podziemne rozłogi, pędy wzniesione, owłosione, kanciaste, słabo rozgałęzione. Odmiana 'Variegata' osiąga wysokość $60 \mathrm{~cm}$, ma liście biało obrzeżone, jajowate lub lancetowate, długości około $7 \mathrm{~cm}$, osadzone okółkowo na całym pędzie. Żółte kwiaty średnicy około $2 \mathrm{~cm}$ wyrastają po kilka z kątów górnych liści, tworząc długie, ulistnione grona. Płatki kwiatów są pokryte drobnymi, gruczołkowatymi włoskami. Tojeść odznacza się długim (od czerwca do sierpnia) i obfitym kwitnieniem. Lysimachia punctata jest jedną z najważniejszych bylin, wykorzystywaną do obsadzania naturalistycznych przestrzeni, nadaje

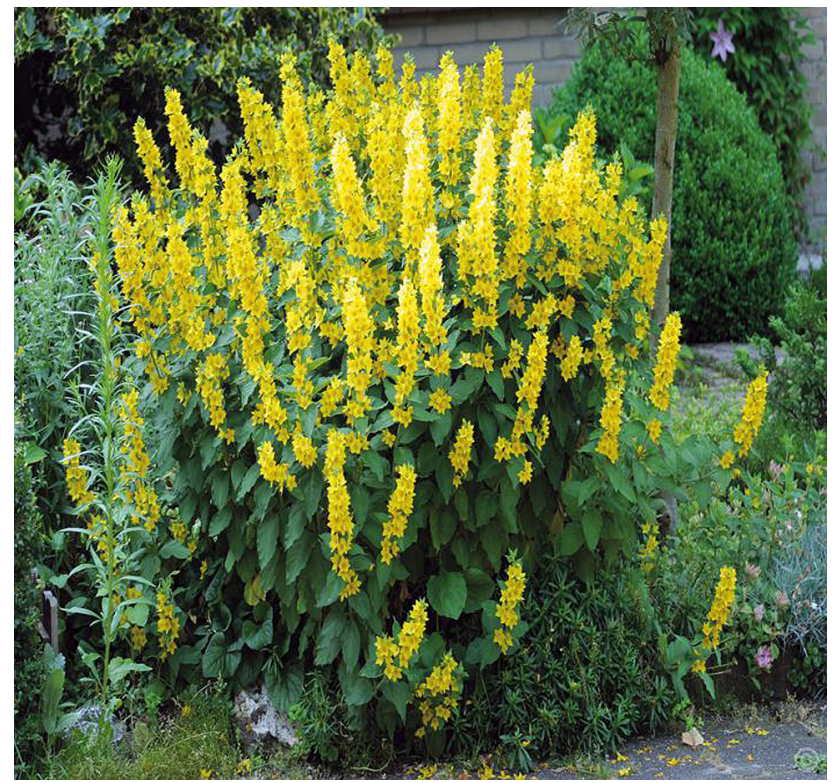

Fot. 5. Lysimachia punctata

Źródło: [5].

Phot. 5. Lysimachia punctata

Source: [5].

się również na rabaty. Sprawdza się jako roślinność towarzysząca zbiornikom wodnym, dobrze znosi okresowe zalanie wodą. Jest rośliną mrozoodporną i długowieczną. Równie dobrze czuje się w słońcu, jak i na ocienionych stanowiskach, pod warunkiem, że podłoże jest żyzne, najlepiej gliniaste lub ilaste, średnio wilgotne do wilgotnego (fot. 5).

\section{WIELOSIŁ BŁEKITNY \\ (POLEMONIUM CAERULEUM 'ALBUM')}

Należy do rodziny Polemoniaceae - wielosiłowate. Rodzima bylina, występująca na mokrych łąkach i w zaroślach. Wielosił rośnie w Polsce na naturalnych

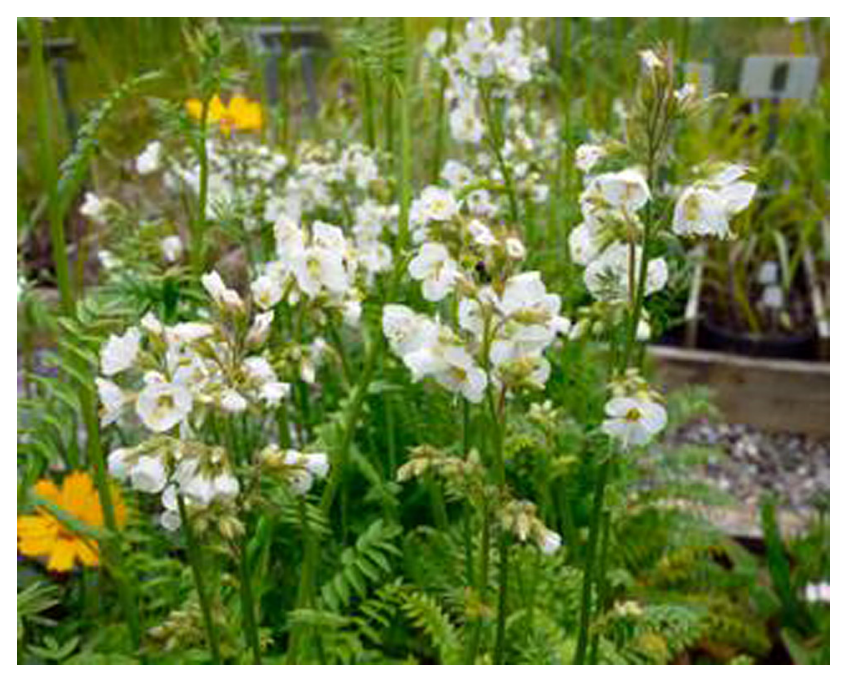

Fot. 6. Polemonium caeruleum 'Album' Źródło: [6].

Phot. 6. Polemonium caeruleum 'Album'

Source: [6]. 
stanowiskach, jest pod ochroną. Forma album osiąga wysokość ok. $60 \mathrm{~cm}$. Ma wyprostowane, kanciaste, puste, dołem gładkie, w górnej części gruczołowate łodygi. Liście pierzaste, dolne na ogonkach, górne siedzące, z 17-27 podługowato-lancetowatymi siedzącymi listkami barwy ciemnozielonej. Otwarte białe kwiaty z żółtymi pylnikami są zebrane w wierzchołkowe wiechy i nadają się do cięcia. Kwitnie od czerwca do lipca. Kwiaty wielosiłu chętnie odwiedzają pszczoły i inne błonkówki. Wielosił błękitny nadaje się do sadzenia na rabatach, w założeniach naturalistycznych i na wilgotnych łąkach lub między krzewami, nad brzegiem wody. W medycynie ludowej ziele wielosiłu stosowano jako środek uspokajający. Bylina najlepiej rośnie na glebach próchnicznych i żyznych, kwaśnych lub lekko kwaśnych, przepuszczalnych, na stanowiskach wilgotnych, nie lubi suszy (fot. 6).

\section{WIĄZÓWKA BŁOTNA (FILIPENDULA ULMARIA)}

Należy do rodziny Rosaceae - różowate. Jest rośliną rodzimą, występującą na wilgotnych łąkach oraz nad brzegami wód. Osiąga wysokość do $200 \mathrm{~cm}$. Łodygi ma obficie ulistnione, liście złożone, $z$ listkiem wierzchołkowym większym od szerokojajowatych, zaostrzonych listków bocznych. Żółtawobiałe, pachnące kwiaty są zebrane w duże podbaldachy. Kwitnie od czerwca do sierpnia. Nadaje się do naturalistycznych nasadzeń nad brzegami wód, razem z krwawnicami i innymi podobnymi bylinami. Jest łatwa do

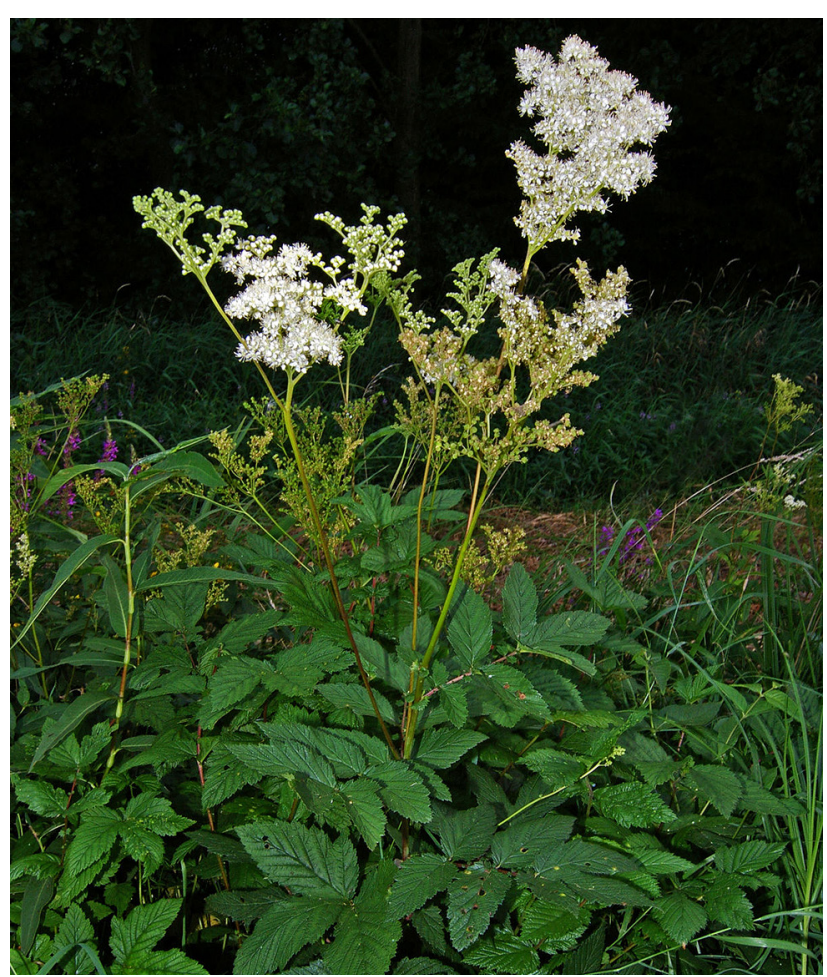

Fot. 7. Filipendula ulmaria Źródło: [7].

Phot. 7. Filipendula ulmaria

Source: [7]. uprawy, wymaga jedynie dość wilgotnego stanowiska, szczególnie w okresie wyrastania pędów kwiatostanowych. Przy odpowiedniej wilgotności gleby znosi nasłonecznienie, ale lepiej uprawiać ją w półcieniu (fot. 7).

\section{GRĄŻEL ŻÓETY (NUPHAR LUTEA)}

Roślina wodna kwitnąca i pachnąca. Liście pływające, skórzaste, owalne, $\mathrm{z}$ głęboko wciętą nasadą $\mathrm{w}$ kolorze od zielonego do brunatnozielonego. Część liści zanurzona, o pokroju sałatowatym. Kwitnie od czerwca do sierpnia. Kwiaty żółte, duże, o średnicy $4-6 \mathrm{~cm}$, silnie pachnące (zapach podobny do zapachu jabłek), z licznymi płatkami korony i 5 działkami kielicha. Wewnątrz kwiatów słupek, który składa się z 5-24 zrośniętych owocolistków. Przedsłupne lub równoczesne kwiaty wyrastają pojedynczo nad wodą na długich szypułkach do $2 \mathrm{~m}$ długości. Grążel ma długie i rozgałęzione kłącze, które rośnie w mule dennym. Owoce w kształcie szerokiej butelki z niereguralnymi pęknięciami. Zasiedla wody stojące lub lekko płynące, eutroficzne w strefie przybrzeżnej, o głębokości od 0,5 do 3,0 m (fot. 8).

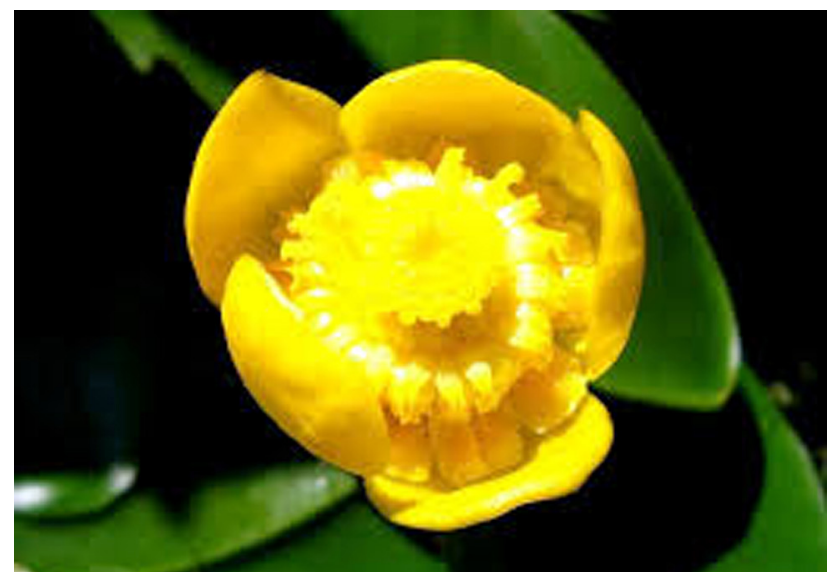

Fot. 8. Nuphar lutea

Źródło: [8].

Phot. 8. Nuphar lutea

Source: [8].

\section{GRZYBIEŃ (NYMPHAEA 'ALBA' I 'ANDREANA')}

Roślina wodna, kwitnąca. Kwitnie obficie od czerwca do września/października. Odmiany: 'Alba' kwitnąca na biało i 'Andreana', w kolorze ciemnoczerwonym, mają kwiaty w kształcie kielicha trzymane kilka centymetrów nad wodą. Średnica kwiatów może osiągnąć kilkanaście centymetrów. Kielich kwiatowy czterodziałowy z licznymi płatkami do 20 sztuk. Liście odmiany 'Alba' skórzaste, o średnicy ok. 30 cm, w kolorze soczystej zieleni, a odmiany 'Andreana' ciemnozielone, pokryte atrakcyjnymi czerwonobrązowymi plamami. Wymaga stanowisk słonecznych i wód o głębokości od 0,15 do 0,6 m (fot. 9a i b). 

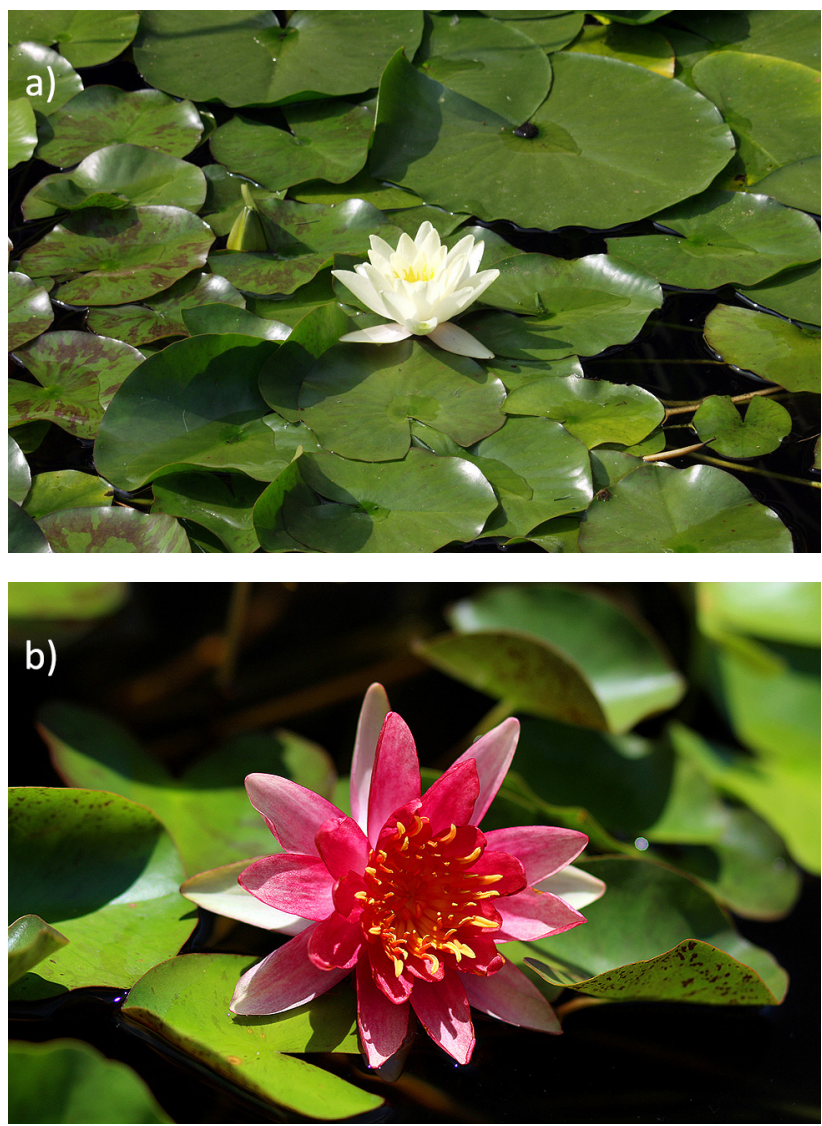

Fot. 9a-b. Nymphaea 'Andreana' Źródło: a - P. Urbański, b - [9].

Phot. 9a-b. Nymphaea 'Andreana'

Source: a - P. Urbański, b - [9].

\section{GRZYBIEŃ (NYMPHAEA 'AMABILIS’)}

Roślina wodna, kwitnąca, pachnąca. Kwitnie obficie od czerwca do września. Kwiaty o średnicy ok. $20 \mathrm{~cm}$, różowe $z$ jaśniejszymi końcami i srebrzystoróżowymi działkami w kształcie gwiazdy, trzymane

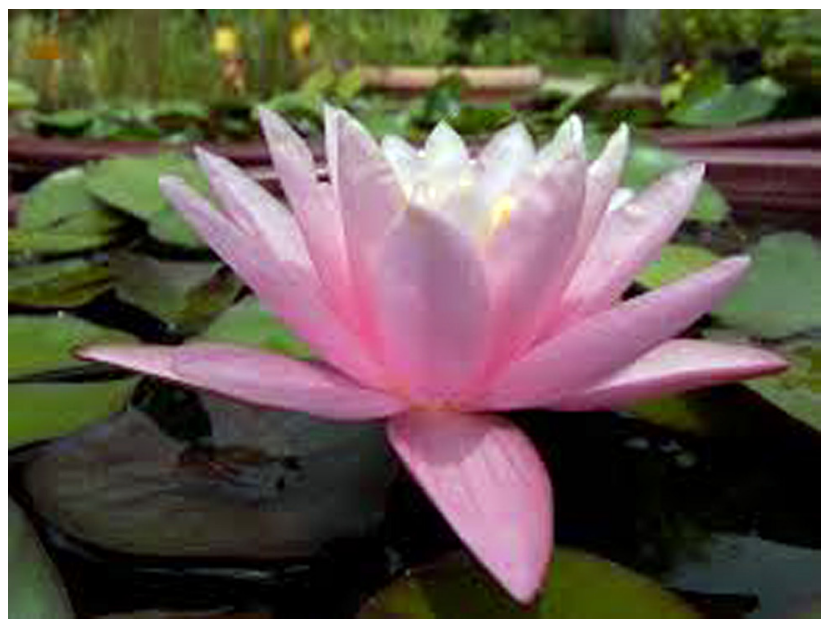

Fot. 10. Nymphaea 'Amabilis' Źródło: [10].

Phot. 10. Nymphaea 'Amabilis'

Source: [10] kilka centymetrów nad wodą. Kielich kwiatowy czterodziałowy, z licznymi płatkami - do 20 sztuk. Liście pływające, owalne, czerwonawe, gdy są młode, a później ciemnozielone. Stanowisko słoneczne. Głębokość wód od 0,4 do 1,0 m (fot. 10).

\section{SPARTYNA GRZEBIENIASTA \\ (SPARTINA PECTINATA 'AUREOMARGINATA')}

Inną projektowaną trawą, niższą od miskanta cukrowego, jest spartyna grzebieniasta, która często mu towarzyszy i jest jego dopełnieniem kompozycyjnym (fot. 11).

Roślina o przewieszających się liściach. Należy do rodziny Poaceae - wiechlinowate. W warunkach naturalnych rośnie na terenach bagiennych Ameryki Północnej. Wyrasta do $150 \mathrm{~cm}$. Tworzy gęste kępy z krótkimi rozłogami. Liście o ostrych brzegach długości do $60 \mathrm{~cm}$, szerokości $2 \mathrm{~cm}$, zwężające się w długi szpic. U odmiany 'Aureomarginata' charakteryzują się wąskim, żółtym obrzeżeniem. Liście są odporne na warunki atmosferyczne. Po zaschnięciu pozostają ozdobne przez całą zimę, więc należy je ścinać dopiero na wiosnę. Kwiatostany długości $20-40 \mathrm{~cm}$ nie mają wartości dekoracyjnej. Nadaje się do wysadzania $\mathrm{w}$ większych grupach na glebach niekoniecznie bagiennych, a także do obsadzania fragmentów

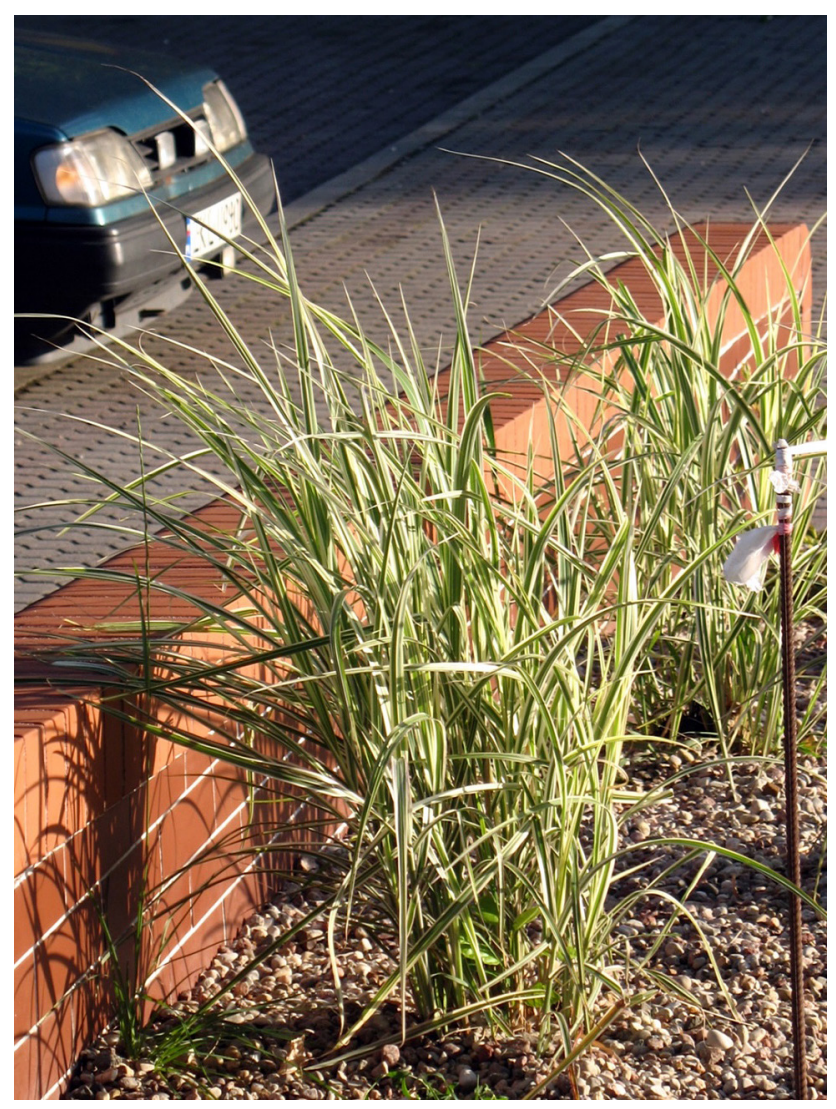

Fot. 11. Spartina pectinata 'Aureomarginata' Źródło: URBAŃSKI (2001).

Phot. 11. Spartina pectinata 'Aureomarginata' Source: URBAŃSKI (2001). 
parków o charakterze naturalnym. Spartyna wykazuje dużą tolerancję na zróżnicowane warunki siedliskowe, rośnie nawet na glebie jałowej, znosi suszę i zacienienie (URBAŃSKI 2001).

\section{MISKANT CUKROWY (MISCANTHUS SACCHARIFLORUS)}

Gatunek należy do rodziny Poaceae - wiechlinowate (fot. 12). W stanie naturalnym występuje na wschód od jeziora Bajkał, głównie w dorzeczu Amuru oraz między Sachalinem a Półwyspem Koreańskim, rośnie również w Japonii. Osiąga wysokość $180 \mathrm{~cm}$. Liście równowąskie, długości $40-60 \mathrm{~cm}$, szerokości do 2 $\mathrm{cm}, \mathrm{z}$ czerwonobrązowym paskiem wzdłuż środkowego nerwu. Późnym latem liście przebarwiają się na brązowoczerwono. Kwiatostan długości 10-20 $\mathrm{cm}$, srebrzysty, jedwabny, dekoracyjny od sierpnia do zimy. Trawa o niewielkich wymaganiach. Dobrze rośnie na każdej glebie, nawet suchej i jałowej. Silnie się rozrasta, nadaje się więc do większych naturalistycznych nasadzeń (URBAŃSKI 2001).

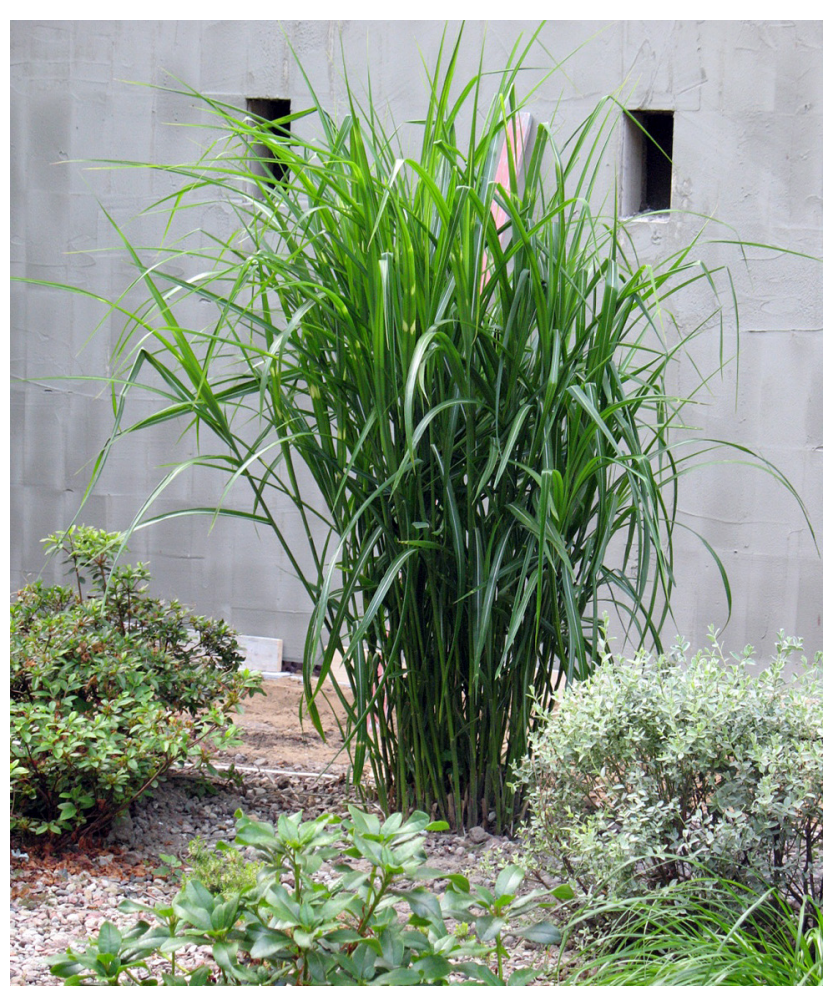

Fot. 12. Miscanthus sacchariflorus 'Robustus' Źródło: URBAŃsKI (2001).

Phot. 12. Miscanthus sacchariflorus 'Robustus' Source: URBAŃSKI (2001).

\section{PODSUMOWANIE}

Zastosowanie roślinności wodnej i terenów podmokłych oraz zakomponowanie jej siedlisk w różnych formach, na przykład owalu naśladującego przebieg brzegów stawu, skupisk roślin na wyspach i terenie sąsiadującym, oraz zagospodarowanie roślinami wodnymi wód zbiornika pozwala na zrealizowanie przestrzeni parku o zbliżonych do naturalnych walorach krajobrazu otwartego $\mathrm{w}$ przestrzeni miasta. W przypadku parku Wodnego w Poznaniu w układ użytkowy udało się również wkomponować tereny poza parkiem - promenadę na wysokim zachodnim brzegu Warty wraz z nowymi nasadzeniami. Istotnym aspektem projektowanego zagospodarowania parku są funkcje: dydaktyczna, estetyczna i wypoczynkowa, a także prospołeczna i proekologiczna, które w dobie wszechobecnych technologii cyfrowych mogą pozytywnie oddziaływać na kondycję i zdrowie człowieka. Projekt zagospodarowania parku i program działań inwestycyjnych pozwala sądzić, że ten istotny dla miasta fragment krajobrazu otwartego terenów zalewowych będzie mógł nadal istnieć $\mathrm{w}$ przestrzeni Poznania. Utrzymanie i renaturyzacja obszarów wód i terenów zalewowych służy wzbogacaniu krajobrazu zurbanizowanego i utrzymaniu jego bioróżnorodności. Obecnie można pozyskać na ten cel środki z funduszy strukturalnych, które pozwalają na zachowanie atrakcyjności form zieleni i walorów miejsca oraz zorganizowanie przestrzeni miejskiej o indywidualnym charakterze.

\section{LITERATURA}

Jaros A., Pracka J., Przybyła J. (2013): Projekt zagospodarowania fragmentu Lubonia. Praca semestralna wykonana pod kierunkiem P. Szumigały w Katedrze Terenów Zieleni i Architektury Krajobrazu UP, Poznań. Materiał niepublikowany.

Komentarz do mapy sozologicznej w skali 1:50 000, arkusz N-33-130-D Poznań. Źródło: http:// www.poznan.pl/mim/wos/mapa-sozologiczna,doc, 1035/mapa-sozologiczna,5906.html (dostęp: 27.11.2018).

Mapa sozologiczna południowego Poznania 1:50000. Źródło: https://www.google.pl/search?q=map$\mathrm{a}+$ sozologiczna + po\%C5\%82udniowego $+\mathrm{Poz}$ nania\&oq $=$ mapa + sozologiczna + po $\%$ C $5 \% 82 u$ dniowego + Poznania\&aqs $=$ chrome.. 69i57.217 27j1j7\&sourceid $=$ chrome $\&$ ie $=$ UTF- 8 (dostęp: 27.11.2018).

Miejscowy plan zagospodarowania przestrzennego dla obszaru „Rejon Marlewa - Zakole Warty” w Poznaniu - uchwała nr LXXX/1204/V/2010 Rady Miasta Poznania z dnia 9 listopada 2010. Urząd Miejski w Poznaniu.

Prognoza oddziaływania na środowisko na potrzeby miejscowego planu zagospodarowania przestrzennego dla obszaru „Rejon Marlewa - Zakole Warty" w Poznaniu. Urząd Miejski w Poznaniu.

URBAŃski P. (2001): Trawy ozdobne, turzyce i sity. PWRiL, Warszawa. 


\section{ŹRÓDŁA INTERNETOWE}

[1]

https://www.google.pl/search?q=Salix + purpurea $+\% 27 \mathrm{Nana} \% 27 \&$ client $=$ firefox-b\&dcr $=$ $0 \& \mathrm{tbm}=\mathrm{isch} \&$ source $=i \mathrm{u} \& \mathrm{ict} \mathrm{x}=1 \& \mathrm{fir}=\mathrm{C} 5 \mathrm{r}$ 0mGxXuzcpYM\%253A\%252CpNOyF5 ePuu28M\%252C_\&usg $=$ WLqmHRzh5ESWhlIsN ofOvMky2eA\%3D\&sa=X\&ved=0ahUKEwjepOG Jut_YAhVLhaYKHQgABM0Q9QEIOTAC\#imgr[2] $\mathrm{c}=\overline{\mathrm{C}} 5 \mathrm{r} 0 \mathrm{mGxXuzcpYM}$ : (dostęp: 27.09.2018).

https://www.webareal.cz/ceskerostliny/eshop/0/0/5/560-Cornus-alba-Elegantissima (dostęp: 27.09.2018).

[3]

https://www.google.pl/search?biw =1122\&bih = $678 \& \mathrm{tbm}=\mathrm{isch} \& \mathrm{sa}=1 \& \mathrm{ei}=\mathrm{VxAEXOGlCMqW}$ sAfNvLOABg\&q = Viburnum + opulus \&oq $=$ Vib urnum + opulus\&gs_l=img.3..014j0i3016.17190 0.209710..210741...0.0..0.104.1611.13j4_.....0. ...1j2..gws-wiz-img....0.scfAZfEeFWg (dostęp: [4] 27.09.2018).

https://www.google.pl/imgres?imgurl=http:// budujesz.info//pliki/image/artykuly/byliny/duze/krwawnica-pospolita3327.jpg\&imgrefurl=http://budujesz.info/artykul/ krwawnica-pospolita-uprawa-odmiany-izastosowanie, 1128.html\&h $=650 \& \mathrm{w}=611 \& \mathrm{tb}-$ nid $=$ CDtEIHfWHbInfM: \&tbnh $=186 \&$ tbn$\mathrm{w}=174 \& u s g=$ eluZd_VBtjql_LcEWu-H7hPdSzg\%3D\&vet $=\overline{1}$ 0ahUKE $\bar{K}$ wiOrNjvt9_YAhWow6YKHdutAhsQ B0IiAEwCg..i\&docid = Dad52 Tar1T-W6M\&itg = 1\&client $=$ firefox-b\&sa $=\mathrm{X} \& \mathrm{~V}$ ed=0ahUKEwiOrNjvt9_YAhWow6YKHdutAh[5] sQ BOIiAEwCg (dostęp: 27.09.2018).

https://www.google.pl/imgres?imgurl=https://albamar.pl/9353-home default/tojesc-kropokowana-lysimachia-punctata.jpg\&imgrefurl=https:// albamar.pl/byliny/918-tojesc-kropokowana-lysimachia-punctata.html \&h=270\&w $=270 \& \mathrm{tb}-$ nid =0r34QG6I2Ied8M: \&tbnh = 186\&tbn$\mathrm{w}=186 \& \mathrm{usg}=$ =_q1vW5QBHxLG-gG69NSomqATBAxA\%3D\&vet $=10$ ahUKEwjG4ZLXuN YAhWFDSwKHVBLDioQ B0IjQEwCg..i\&doci$\mathrm{d}=\mathrm{WwBSqn} 1$ oeBgN2M\&itg $=1$ \&client $=$ firefox -b\&sa =X\&ved=0ahUKEwjG4ZLXuN_YAhWFDSwKHVBLDioQ B0IjQEwCg\#h=270\&imgdii=_yfzp0epKp9tM:\&tbnh=186\&tbn - $\mathrm{w}=186 \& v e t=10$ ahUKEwjG4ZLXuN_YAhWFDSwKHVBLDioQ B0IjQEwCg..i\&w=270 (dostęp: 27.09.2018).

[6]

https://www.google.pl/search?q=Polemonium + caeruleum + f. + album \&client $=$ firefox-b\&dcr $=0 \& \mathrm{tbm}=\mathrm{isch} \&$ source $=\mathrm{iu} \& \mathrm{ict} \mathrm{x}=1 \& \mathrm{fir}=\mathrm{o} 3 \mathrm{c}$ ZrZSzXthxsM\%253A\%252CoioJ f07GL5PUM\%252C_\&usg= dTfKJHFj5o9f9jFxlizqnHj qVSs\%3D\&sa $=$ X\&ved $=0$ ahUKEwjewvudud YAhUDCpoKHQG2BHsQ9QEIOzAE\#imgrc =o3cZrZSzXthxsM: (dostęp: 27.09.2018).

[7]

https://www.google.pl/imgres?imgurl=https://upload.wikimedia.org/wi$\mathrm{k}$ i p ed i a / c o m m o n s/t h u m b/c/c 7/ FilipendulaUlmaria.jpg/1200px-FilipendulaUlmaria.jpg\&imgrefurl = https://pl.wikipedia . org/wiki/Wi\%25C4\%2585z\%25C3\%25B3w-

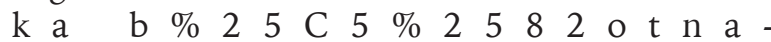
$\& \mathrm{~h}=\overline{1} 838 \& \mathrm{w}=1200 \& \mathrm{tbnid}=\mathrm{OI} 51 \mathrm{unYSLv} 4 \mathrm{U}$ $2 \mathrm{M}: \& \mathrm{tbnh}=186 \& \mathrm{tbnw}=121 \& \mathrm{usg}=\mathrm{a} 7 \mathrm{gGn}-$ 5diOpnPz7ya9Mf3Vmnqyuc\%3D\&vet=10ahUKEwiE_Pnbud_YAhVBsywKHV8JAZwQ_B0IiAEwCg...i\&docid=WoLALa9D5pfSeM\&itg = $1 \&$ client $=$ firefox $-\mathrm{b} \& \mathrm{sa}=\mathrm{X} \& \mathrm{ved}=0 \mathrm{ahUKEw}$ iE Pnbud YAhVBsywKHV8JAZwQ BOIiAEwCg (dostęp: 27.09.2018).

[8]

https://www.google.pl/search?q=gr\%C4\%85\%C$5 \%$ BCel $+\%$ C5\%BC\%C3\%B3\%C5\%82ty\&sour $\mathrm{ce}=\operatorname{lnms} \& \mathrm{tbm}=\mathrm{isch} \& \mathrm{sa}=\mathrm{X} \& \mathrm{ved}=0 \mathrm{ahUKEwj} 4$ w--SyYHfAhVHjiwKHZK4D1YQ AUIDigB\&bi$\mathrm{W}=1068 \& \mathrm{bih}=674 \#$ imgrc $=Z \mathrm{ZYb} 7 \mathrm{~s} 2 \mathrm{~W} 36 \mathrm{asTKM}$ : (dostęp: 27.09.2018)

[9]

https://www.internationalwaterlilycollection. com/?project = nymphaea-andreana (dostęp: 27.09.2018)

[10]

https://www.google.pl/search?q=Nymphaea $+\mathrm{A}$ mabilis \& source $=\operatorname{lnm}$ s $\&$ tbm $=$ isch \&sa $=X \& v e$ d=0ahUKEwjI-eTQ6YHfAhWH_aQKHcZhC4sQ AUIDigB\&biw $=1124 \&$ bih $=7 \overline{2} 8$ (dostęp: 27.11.2018).

For citation: SZUMigaŁa P.P., URBAŃSKI P., WALERZAK M., SzumigaŁa K. (2018): Zieleń wodna i terenów zalewowych w parku Wodnym w Poznaniu. Steciana 22, 3: 85-95. doi: 10.12657/steciana.022.010 